\title{
Improved procedure for the preparation of 7-methoxy-2-methyl-1- (2-morpholinoethyl)-1H-indole-3-carboxylic acid, key intermediate in the synthesis of novel 3-amidoindole and indolopyridone cannabinoid ligands
}

\author{
Rulin Zhao,* Bei Wang, Hong Wu, John Hynes, Jr., Katerina Leftheris, \\ Balu Balasubramanian, Joel C. Barrish and Bang-Chi Chen \\ Discovery Chemistry, Bristol-Myers Squibb Research and Development, Princeton, NJ 08543 , \\ USA \\ E-mail: Rulin.zhao@bms.com
}

Dedicated to Professor Franklin A Davis on his $\mathbf{7 0}^{\text {th }}$ birthday

\begin{abstract}
A new efficient method was developed for the preparation of 2-methyl-1-(2-morpholinoethyl)1H-indole-3-carboxylic acid. The new method involves N-alkylation of 7-methoxy-2methylindole with 4-(2-chloroethyl)morpholine hydrochloride followed by trichloroacetylation and hydrolysis in 3 steps and $88 \%$ overall yield.
\end{abstract}

Keywords: cannabinoid (CB2) receptor, synthesis, indole N-alkylation, indole-3-carboxylate.

\section{Introduction}

The discovery of the human peripheral cannabinoid (CB2) receptor, ${ }^{1}$ has stimulated a significant amount of research effort on the development of CB2 selective ligands. ${ }^{2-4}$ In our search for novel cannabinoid receptor modulators, it was discovered that 7-methoxy-2-methyl-1-(2morpholinoethyl)-N-((1S,2S,4R)-1,3,3-trimethylbicyclo[2.2.1] heptan-2-yl)-1H-indole-3-

carboxamide 1 binds selectively to the CB2 receptor and displays excellent in vivo potency against LPS induced TNF- $\alpha$ release in murine models of cytokine production. ${ }^{3}$. Further optimization led to a novel cannabinoid ligand $\mathbf{2}$ which shows high affinity for the CB2 receptor $\left(\mathrm{K}_{i}=1.0 \mathrm{nM}\right)$ and possesses anti-inflammatory properties when administered orally in an in vivo murine inflammation model. ${ }^{4}$ This novel C-3 amido indole and its cyclized and conformationally constrained indolopyridone cannabinoid receptor modulators $\mathbf{1}$ and $\mathbf{2}$ are derivatives of indole-3- 
carboxylates. The morpholino acid, 7-methoxy-2-methyl-1-(2-morpholinoethyl)-1H-indole-3carboxylic acid (3) is an advanced core intermediate en route to both of these compounds.,

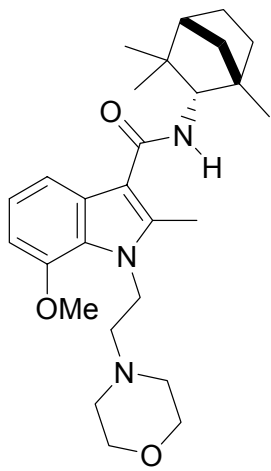

1

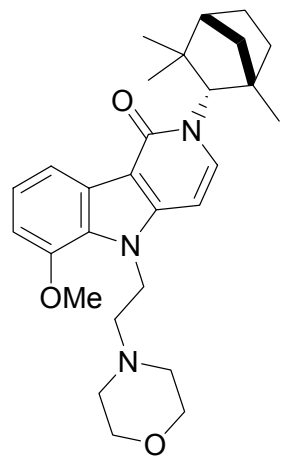

2

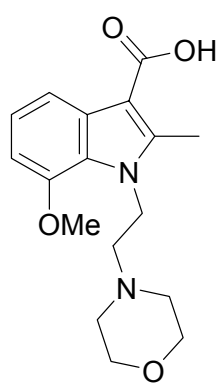

3

Previously, 7-methoxy-2-methyl-1-(2-morpholinoethyl)-1H-indole-3-carboxylic acid 2 was prepared from 7-methoxy-2-methyl-1H-indole 4 as shown in Scheme 1. ${ }^{3}$ Treatment of 4 with 3 equivalents of methylmagnesium bromide in MTBE followed by trapping the anion with ethyl chloroformate afforded ethyl indole-3-carboxylate 5a in 58\% yield after silica gel chromatography. Alternatively, the indole-3-carboxylate could be prepared by acylation of 7methoxy-2-methyl-1H-indole 4 with trichloroacetyl chloride followed by alcoholysis. ${ }^{3,5}$ An example of this preferred approach is the preparation of methyl indole-3-carboxylate $\mathbf{5 b}$, which was obtained in $92 \%$ yield. $^{3}$

The introduction of the N-morpholinoethyl side chain onto the indole-3-carboxylate 5 was accomplished by treating 5 with 4-(2-chloroethyl)morpholine hydrochloride $\mathbf{6}$ in the presence of a large excess of base. Thus, treatment of ethyl indole-3-carboxylate 5a with 4 equivalents of sodium hydride followed by addition of 6 gave ethyl 7-methoxy-2-methyl-1-(2morpholinoethyl)-1H-indole-3-carboxylate 7 in $62 \%$ yield after purification by silica gel chromatography. Hydrolysis of 7 with $\mathrm{NaOH}$ in methanol and water and subsequent neutralization to $\mathrm{pH}$ 6.5-7 afforded 3 in $71 \%$ isolated yield. While this approach provided a small quantity of the desired indole-3-carboxylic acid 3 to fuel SAR studies, it was not amenable for scale-up synthesis due to the use and handling of a large excess of hazardous sodium hydride, the generation of hydrogen gas in the reaction, as well as the needs for chromatographic separation of by-products 8 and 9 resulting from the competitive C-alkylation at the 2-methyl group in $\mathbf{5}$ under the reaction conditions. ${ }^{6}$ Herein, we report a new and improved procedure for the preparation of 7-methoxy-2-methyl-1-(2-morpholinoethyl)-1H-indole-3-carboxylic acid 3 (Scheme 2). 


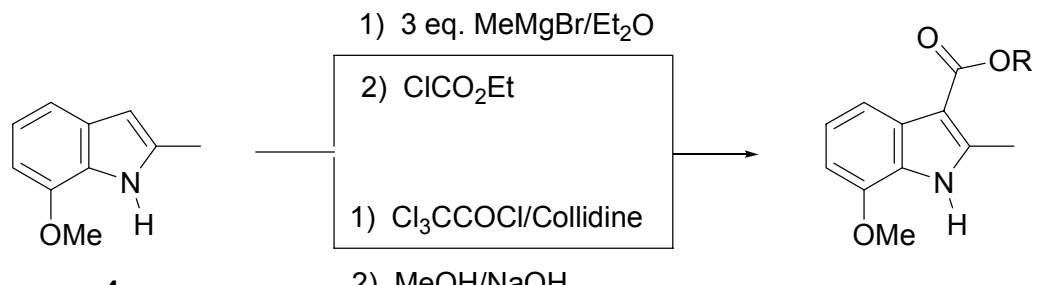

4

2) $\mathrm{MeOH} / \mathrm{NaOH}$

5a, $\mathrm{R}=\mathrm{Et}, 58 \%$

5b, $R=M e, 92 \%$

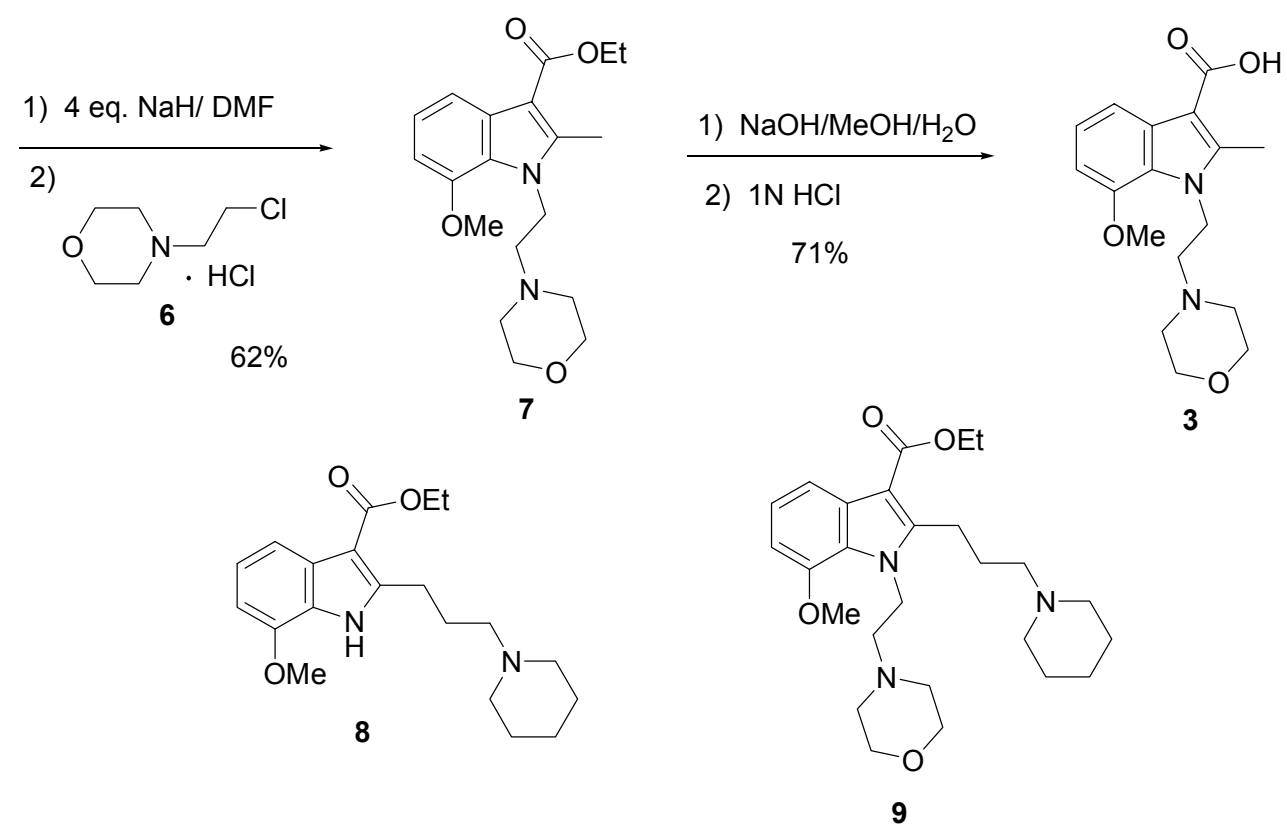

\section{Scheme 1}
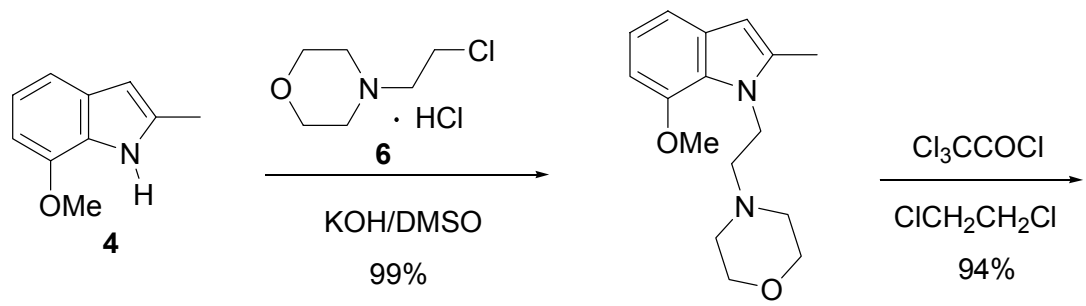

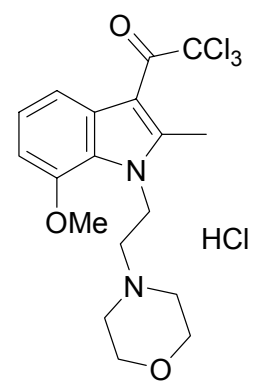

11

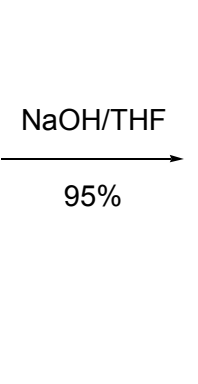

10

\section{Scheme 2}




\section{Results and Discussion}

Our rationale for developing the new and improved synthesis of 7-methoxy-2-methyl-1-(2morpholinoethyl)-1H-indole-3-carboxylic acid 3 as shown in Scheme 2 was based on the following considerations. First, we believed that the undesired competitive C-alkylation at the 2methyl group in $\mathbf{5}$ in the previous synthesis (scheme 1) was a result from increase of acidity of the 2-methyl group, a consequence of the introduction of the 3-carboxylate group in $\mathbf{5}$ through a vinylogous carbonyl effect. We envisioned that if the indole $\mathrm{N}$-alkylation was carried out prior to introduction of the 3-carboxylate group, the undesired competitive C-alkylation at the 2-methyl group would disappear. Second, we would like to take advantage of the much more desired nonmetallic method that we developed earlier for the synthesis of indole-3-carboxylate $\mathbf{5 b}$ using trichloroacetyl chloride.

Thus, treatment of 7-methoxy-2-methyl-1H-indole 4 with 1.4 equivalents of 4-(2chloroethyl)morpholine hydrochloride 6 in DMSO using 4 equivalents $\mathrm{KOH}$ as base gave 4-(2(7-methoxy-2-methyl-1H-indol-1-yl)ethyl)morpholine 10 smoothly (Scheme 2). The use of a strong base such as $\mathrm{NaH}$ was found to be unnecessary for this reaction and the concerns of handling $\mathrm{NaH}$ and generation of hydrogen gas on scale-up were eliminated. More importantly, by using a weaker base $(\mathrm{KOH})$, the undesired C-alkylations were not observed, resulting in higher yield and simpler product isolation and purification. After extractive workup to remove the water soluble inorganic salts and excess 4-(2-chloroethyl)morpholine, the desired product 10 was obtained in essentially quantitative yield whithout chromatographic purification.

With an efficient approach to intermediate $\mathbf{1 0}$ in hand, our next goal was the introduction of the 3-carboxylate group to 10. The 3-acylation was initially tried using the trichloroacetyl chloride and collidine as the base. The reaction took place to give the desired product, but it was sluggish. After 2 hours of refluxing, the desired product 11 was formed in 28\% by LC/MS. Longer heating resulted in decomposition of the product. Considering the fact that the starting compound $\mathbf{1 0}$ has a basic nitrogen in the morpholine ring, we decided to run the acylation reaction without the use of external base. To our delight, the reaction was fast and completed in 6-8 hours under reflux in 1,2-dichloroethane. The reaction was also very clean, resulting in again a very simple work-up and product isolation and purification. After cooling the reaction mixture to room temperature, the desired product 11 was isolated in $94 \%$ yield as a hydrochloride salt after filtration of the resulting slurry. Final hydrolysis of 11 to 7-methoxy-2-methyl-1-(2morpholinoethyl)-1H-indole-3-carboxylic acid 3 was uneventful. By running the reaction with aqueous $1 \mathrm{~N} \mathrm{NaOH}$ in THF, 7-methoxy-2-methyl-1-(2-morpholinoethyl)-1H-indole-3-carboxylic acid 3 was isolated in $95 \%$ yield after $\mathrm{pH}$ adjustment of the reaction mixture using $\mathrm{HCl}$. 


\section{Conclusions}

In summary, a new and efficient method was developed for the preparation of 2-methyl-1-(2morpholinoethyl)-1H-indole-3-carboxylic acid. The new method involves $\mathrm{N}$-alkylation of 7methoxy-2-methylindole with 4-(2-chloroethyl)morpholine hydrochloride followed by trichloroacetylation and hydrolysis in 3 steps and $88 \%$ overall yield. The new process was readily scaled-up and no chromatographic separation of products was involved. The new method was successfully applied to the synthesis of novel 3-amidoindole and indolopyridone cannabinoid ligands. Furthermore, it is expected that this new method can be applied to the preparation of other aminoalkylindoles, biologically important and medicinally useful agents.

\section{Experimental Section}

General. Proton NMR spectra were recorded with a Bruker DRX-400 spectrometer using $\mathrm{CDCl}_{3}$ or DMSO- $\mathrm{d}_{6}$ as solvent and TMS as an internal standard. Chemical shifts $(\delta)$ are given from TMS $(0 \mathrm{ppm})$ as internal standard for proton NMR. All other reagents and solvents were commercial products and were used as received unless otherwise noted. All reactions were monitored by HPLC using a Shimadzu LC-10AS system and YMS ODS-A S5 4.6x50mm column with linear gradient system of $\mathrm{H}_{2} \mathrm{O}-\mathrm{MeOH}-\mathrm{H}_{3} \mathrm{PO}_{4}$ 90:10:0.2 to 10:90:0.2 over 4 min. and at a flow rate of $4 \mathrm{~mL} / \mathrm{min}$. All compounds were of $>99 \%$ purity by analytical HPLC analyses. Melting points are uncorrected.

Preparation of 1-[2-(4-morpholino)ethyl)-2-methyl-7-methoxyindole 10. To a stirred suspension of $130.2 \mathrm{~g}(0.7 \mathrm{~mol})$ of $\mathrm{N}$-(2-chloroethyl)morpholine hydrochloride 6 in $1 \mathrm{~L}$ of DMSO was added $132 \mathrm{~g}(2 \mathrm{~mol})$ of $85 \%$ powdered $\mathrm{KOH}$. After the suspension was stirred for 5 minutes, a solution of $80.6 \mathrm{~g}(0.5 \mathrm{~mol})$ of 2-methyl-7-methoxyindole $\mathbf{4}^{7}$ in $200 \mathrm{~mL}$ of DMSO was added. After stirring for 10 minutes, the reaction mixture was heated to $100^{\circ} \mathrm{C}$ and stirred at this temperature for 3.5 hours. The reaction mixture was cooled to ambient temperature and diluted with $1 \mathrm{~L}$ of water and $2 \mathrm{~L}$ of MTBE. The organic layer was separated and aqueous layer was extracted with MTBE $(2 \times 1 \mathrm{~L})$. The organic layers were combined, washed with brine $(1 \mathrm{~L})$. The solvent was removed under reduced pressure to give $135.9 \mathrm{~g}$ product 10 as a light yellow oil (99\%). ${ }^{1} \mathrm{H}$ NMR $\left(\mathrm{CDCH}_{3}\right) \delta 2.42(\mathrm{~s}, 3 \mathrm{H}), 2.52(\mathrm{~m}, 4 \mathrm{H}), 2.62(\mathrm{t}, J=7.1 \mathrm{~Hz}, 2 \mathrm{H}), 3.75(\mathrm{~m}, 4 \mathrm{H})$, $3.90(\mathrm{~s}, 3 \mathrm{H}), 4.42(\mathrm{t}, J=7.1 \mathrm{~Hz}, 2 \mathrm{H}), 6.17(\mathrm{~s}, 1 \mathrm{H}), 6.55(\mathrm{~d}, J=7.8 \mathrm{~Hz}, 1 \mathrm{H}), 6.90$ (dd, $J=7.8,8.0 \mathrm{~Hz}$, $1 \mathrm{H}), 7.10(\mathrm{~d}, J=8.0 \mathrm{~Hz}, 1 \mathrm{H})$. MS calcd for $\mathrm{C}_{16} \mathrm{H}_{22} \mathrm{~N}_{2} \mathrm{O}_{2}[\mathrm{M}+\mathrm{H}] 275.168$, found 265.169. Anal. HPLC $\operatorname{tr}=2.19 \mathrm{~min}$.

Preparation of 1-[2-(4-morpholino)ethyl)-2-methyl-3-trichloroacetyl-7-methoxyindole hydrochloride 11. To a solution of $10(132 \mathrm{~g}, 0.48 \mathrm{~mol})$ in 1,2-dichloroethane (2 L) was added trichloroacetyl chloride $(262.4 \mathrm{~g}, 1.44 \mathrm{~mol})$. The solution was refluxed for $6-8 \mathrm{~h}$ and then cooled to ambient temperature. The resulted slurry was filtered, washed with $\operatorname{MTBE}(2 \times 1 \mathrm{~L})$ and dried to 
give $205.8 \mathrm{~g}$ of product $11(94 \%) .{ }^{1} \mathrm{H} \mathrm{NMR}\left(\mathrm{CDCl}_{3}\right) \delta 02.85(\mathrm{~s}, 3 \mathrm{H}), 2.95(\mathrm{~m}, 2 \mathrm{H}), 3.30(\mathrm{~m}$, $2 \mathrm{H}), 3.55(\mathrm{~m}, 2 \mathrm{H}), 4.05(\mathrm{~m}, 5 \mathrm{H}), 4.32(\mathrm{~m}, 2 \mathrm{H}), 5.15(\mathrm{~m}, 2 \mathrm{H}), 6.75(\mathrm{~d}, J=7.8 \mathrm{~Hz}, 1 \mathrm{H}), 7.15$ (dd, $J=7.8,8.0 \mathrm{~Hz}, 1 \mathrm{H}), 7.85(\mathrm{~d}, J=8.0 \mathrm{~Hz}, 1 \mathrm{H})$. MS calcd for $\mathrm{C}_{18} \mathrm{H}_{21} \mathrm{Cl}_{3} \mathrm{~N}_{2} \mathrm{O}_{3}[\mathrm{M}+\mathrm{H}] 419.061$, found 419.065. Anal. HPLC $\operatorname{tr}=2.77 \mathrm{~min}$.

Preparation of 1-[2-(4-morpholino)ethyl)-2-methyl-7-methoxyindole-3-carboxylic acid 3. To a solution of 11 (182.45 g, $0.4 \mathrm{~mol})$ in THF (1 L) was added $\mathrm{NaOH}$ solution $(1 \mathrm{~L}, 1 \mathrm{~N}, 1 \mathrm{~mol})$. The reaction mixture was stirred about 1-2 $\mathrm{h}$. The $\mathrm{pH}$ of the reaction solution was adjusted to 4 with $\mathrm{HCl}(6 \mathrm{~N})$. The slurry was filtered, washed with MTBE $(2 \times 500 \mathrm{~mL})$ and water. The solid was dried to give product 3 (120.58 g, 95\%). ${ }^{1} \mathrm{H}$ NMR (DMSO-d 6$) \delta 2.44(\mathrm{~s}, 3 \mathrm{H}), 2.58(\mathrm{~s}, 2 \mathrm{H})$, $2.72(\mathrm{~s}, 4 \mathrm{H}), 3.56(\mathrm{~s}, 4 \mathrm{H}), 3.90(\mathrm{~s}, 3 \mathrm{H}), 4.42(\mathrm{~s}, 2 \mathrm{H}), 6.67(\mathrm{~d}, J=7.8 \mathrm{~Hz}, 1 \mathrm{H}), 7.00$ (dd, $J=7.8$, $8.0 \mathrm{~Hz}, 1 \mathrm{H}), 7.65(\mathrm{~d}, J=8.0 \mathrm{~Hz}, 1 \mathrm{H}) .318 .158$. MS calcd for $\mathrm{C}_{17} \mathrm{H}_{22} \mathrm{~N}_{2} \mathrm{O}_{4}[\mathrm{M}+\mathrm{H}] 319.158$, found 319.162. Anal. HPLC tr $=1.43 \mathrm{~min}$.

\section{References}

1. Munro, S.; Thomas, K. L.; Abu-Shaar, M. Nature 1993, 365, 61.

2. (a) Huffman, J. W.; Lainton, J. A. H. Curro Med. Chern. 1996, 3, 101. (b) Xiang, J.-N.; Lee, J. C. In Annual Reports in Medicinal Chemistry; Doherty, A. M. Ed.; Academic: San Diego, 1999; Vol. 34, Chapter 20. (c) Krishnamurthy, M.; Li, W.; Moore, B. M. Bioorg. Med. Chem. 2004, 12, 393. (d) Raitio, K. H.; Savinainen, J. R.; Vepsaelaeinen, J.; Laitinen, J. T.; Poso, A.; Jaervinen, T.; Nevalainen, T. J. Med. Chem. 2006, 49, 2022. (e) Manera, C.; Benetti, V.; Castelli, M. P.; Cavallini, T.; Lazzarotti, S.; Pibiri, F.; Saccomanni, G.; Tuccinardi, T.; Vannacci, A.; Martinelli, A.; Ferrarini, P. L. J. Med. Chem. 2006, 49, 5947. (f) Stern, E.; Muccioli, G. G.; Bosier, B.; Hamtiaux, L.; Millet, R.; Poupaert, J. H.; Henichart, J.-P.; Depreux, P.; Goossens, J.-F.; Lambert, D. M. J. Med. Chem. 2007, 50, 5471. (g) Page, D.; Yang, H.; Brown, W.; Walpole, C.; Fleurent, M.; Fyfe, M.; Gaudreault, F.; St-Onge, S. Bioorg. Med. Chem. Lett. 2007, 17, 6183. (h) Ohta, H.; Ishizaka, T.; Tatsuzuki, M.; Yoshinaga, M.; Iida, I.; Tomishima, Y.; Toda, Y.; Saito, S. Bioorg. Med. Chem. Lett. 2007, 17, 6299

3. Hynes, J., Jr.; Leftheris, K.; Wu, H.; Pandit, C.; Chen, P.; Norris, D. J. Chen, B.-C.; Zhao, R.; Kiener, P. A.; Chen, X.; Turk, L. A.; Patil-Koota, V.; McIntyre, K. W.; Shuster, D. J.; Kathleen M. Gillooly, K. M. Bioorg. Med. Chem. Lett. 2002, 12, 2399.

4. Wrobleski, S. T.; Chen, P.; Hynes, H., Jr.; Lin, S.; Norris, D. J.; Pandit, C. R.; Spergel, S.; Wu, H.; Tokarski, J. S.; Chen, X.; Gillooly, K. M.; Kiener, P. A.; McIntyre, K. W.; Patilkoota,V.; Shuster, D. J.; Turk, L. A.; Yang, G.; Leftheris, L. J. Med. Chem. 2003, 46, 2110.

5. Fedouloff, M.; Hossner, F.; Voyle, M.; Ranson, J.; Powles, J.; Riley, G.; Sanger, G.; Bioorg. Med. Chem. 2001, 9, 2119.

6. For previous references on C-alkylations of 2-methyl indole-3-carboxylates, see (a) Joseph, B.; Cornec, O.; Merour, J-Y.; Solans, X.; Font-Bardia, M. J. Heterocycl. Chem. 1997, 34, 
525. (b) Macor, J. E.; Ryan, K.; Newman, M. E. J. Org. Chem. 1989, 54, 4785. (c) Macor, J. E.; Newman, M. E.; Ryan, K. Tetrahedron Lett. 1989, 30, 2509. (d) Mali, R. S.; ManekarTilve, A. Org. Prep. Proced. Int. 1994, 26, 573. (e) Mouaddib, A.; Joseph, B.; Hasnaoui, A.; Merour, J.-Y.; Leonce, S. Heterocycles 1999, 51, 2127.

7. Chen, B.-C.; Hynes, J., Jr.; Pandit, C. R.; Zhao, R.; Skoumbourdis, A. P.; Wu, H.; Sundeen, J. E.; Leftheris, K. Hetereocycles 2001, 55, 951. 